\title{
The Effects of Learning Model and Achievement Motivation on Natural Science Learning Outcomes of Students at State Islamic Elementary Schools in Medan, Indonesia
}

\author{
Wahyudin Nur Nasution (Corresponding Author) \\ Faculty of Teacher Training and Education \\ Universitas Islam Negeri Sumatera Utara, Indonesia \\ E-mail: wahyudinnst70@gmail.com
}

\author{
Received: April 30, $2017 \quad$ Accepted: June 26, $2017 \quad$ Published: August 30, 2017 \\ doi:10.5296/jet.v4i2.11144 URL: http://dx.doi.org/10.5296/jet.v4i2.11144
}

\begin{abstract}
The research aimed to study the effects of learning model and achievement motivation on natural science learning outcomes. It was a 2 x 2 factorial experimental design. The research was conducted at two state Islamic elementary schools in Medan, Indonesia, namely: Medan Tembung State Islamic Elementary School and Medan Sunggal State Islamic Elementary School. Samples in the research were 60 students at the two schools. Data in the research was collected by using an achievement motivation scale and a learning outcome test. Then, the collected data was analyzed by using a two-way analysis of variance (ANOVA). The research found that (1) natural science learning outcomes of students who were taught by using a cooperative learning model were higher than those of students who were taught by using a direct instruction model; (2) natural science learning outcomes of students with high achievement motivation who were taught by using a cooperative learning model were higher than those of students with high achievement motivation who were taught by using a direct instruction model; (3) natural science learning outcomes of students with low achievement motivation who were taught by using a direct instruction model were higher than those of students with low achievement motivation who were taught by using a cooperative learning model and; (4) there was an interaction between learning model and achievement motivation and its effects on natural science learning outcomes.
\end{abstract}

Keywords: Cooperative Learning Model, Direct Instruction Model, Achievement Motivation, Natural Science Learning Outcomes 


\section{Introduction}

Natural science is one of the subjects that must be mastered by students because natural sciences are the basis of technology. It attempts to generate someone's interest in the improvement of his or her intelligence and understanding of nature and its contents which are full of secrets (Sumaji, 1998). Learning natural sciences can help students improve the quality of their lives because in learning natural sciences, they are required to think critically, solve problems and make decisions (Krajcik, Czerniak, \& Berger, 1999). Experience has shown that someone who has learned natural sciences well has better ability to transfer his or her knowledge to other disciplines outside natural sciences (Supriyadi, 1994). This is true because natural science is a discipline which contains not only scientific products but also process through which the products have been created and attitudes or values which serve as basis for the invention process.

Realizing the importance of natural science learning, various efforts have been made to improve the quality of natural science learning at schools such as by revising curriculum, improving teachers' quality and skills, providing and renewing textbooks, providing audio-visual aids for natural science laboratory, developing more relevant and effective approaches that can be used to achieve goals of natural science learning, etc.

Sadly, in general, natural science learning outcomes of students in Indonesia are not satisfying yet. Data from Research and Development Division of the Ministry of Education and Culture of the Republic of Indonesia in 2014 showed that the average score of natural sciences at the national examination was only 6.39 (Ministry of Education and Culture of the Republic of Indonesia, 2014). The low natural science score is caused by internal and external factors. It is assumed that internal factor that may affect students' natural science learning outcomes includes achievement motivation (Irawan, Suciati, \& Wardani, 1997), while external factors that may affect students' natural science learning outcomes include students' learning environment, teachers' skills, facilities and infrastructure as well as learning models used by teachers (Suryabrata, 2005; Al Rasydin \& Nasution, 2015).

Based on situations above, the author was interested in conducting an experiment on the use of a cooperative learning model. It was assumed that the model was effective to improve students' natural science learning outcomes. In this research, we also compared learning outcomes of natural science taught by using a cooperative learning model and those taught by using a direct instruction model to see whether or not the former had an effect on students' natural science learning outcomes. Students' characteristic is an important factor that must be carefully considered by a teacher because it is a determining factor for the successful use of a learning model. Therefore, this research was focused on this internal factor, achievement motivation, as an effort to explore the effect of the use of a learning model on students' natural science learning outcomes. Thus, the research aimed study the effects of learning model and achievement motivation on natural science learning results. 


\section{Review of Literature}

\subsection{Natural Science Learning Outcomes}

\subsubsection{Learning Outcomes}

Learning outcome is a level of knowledge mastery reached by students participating in a learning program in accordance with the set educational goals (Soedijarto, 1993). According to Gagne and Briggs (1992), learning outcome is an ability developed by someone after participating in a learning process. There are five major categories of learning: intellectual skills, cognitive strategies, verbal information, motor skills and attitudes. Bloom (1975) divides learning outcomes into three domains: cognitive, affective and psychomotor. According to Anderson and Krathwohl (2001), learning outcomes in cognitive domain have two dimensions: knowledge dimension and cognitive process dimension. Knowledge dimension is divided into four categories: factual, conceptual, procedural and metacognitive knowledge. Meanwhile, cognitive process dimension is divided into six categories: remember, understand, apply, analyze, evaluate and create. Romiszowski (1981) emphasizes learning outcomes on two aspects: knowledge and skills. Knowledge can be divided into four: facts, procedures, concepts and principles. Similarly, skills can also be divided into four: cognitive, motor, reactive and interactive.

\subsubsection{Natural Science}

Natural science is a discipline that explains the process of observation of nature (Ormrod, 2000). This is in line with the opinion of Amien (1987) stating that natural science is actually the natural world, both in the form of living beings and inanimate objects that can be observed. According to Carin and Sund (1989), natural science is a system of knowledge about the universe obtained through data collection, observation and controlled experiment which includes the processes, products and human behavior.

In elementary education, teachers are expected to encourage students to develop curiosity, objectivity, openness, rational thinking and drawing conclusions based on the available data because these properties are part of the scientific attitude (Cain and Evans, 1990). Scientific attitude implied in the above definitions of natural science is closely related to someone's personality. Both value system and scientific attitude are needed in a scientific process to produce correct explanation and understanding of various natural phenomena.

In general, topics of natural science subjects in the curriculum of Islamic elementary schools (MI) include: (1) living creatures and their lives: humans, animals, plants and their interactions, (2) the material, properties, and uses: air, water, soil, and rocks, (3) electric and magnetic fields, energy and heat, force and simple machines, light and sound, the solar system, the earth, and other planets, (4) health, food, disease and disease prevention, (5) natural resources, usage, preservation and conservation. Meanwhile, in the first semester of the fifth grade of Islamic elementary school (MI), there are seven topics in the natural science subject, namely: (1) human and animal respiratory systems, (2) relationship between digestive system organs and health, (3) blood, (4) green plants, (5) living creature adaptation and their environment (6) material structure, and (7) changes in the nature of objects (Priyono \& Sayekti, 2010). 
Based on the above descriptions of learning outcomes and natural sciences, in this research, natural science learning outcome is defined as the mastery of topics of natural science subjects which include changes in knowledge dimensions (factual, conceptual and procedural knowledge) and cognitive process dimension (remember, understand, apply, analyze, evaluate and create) by students as a result of the process of natural science learning gone through over a period of time based on the set learning objectives.

\subsection{Cooperative Learning Model and Direct Instruction Model}

\subsubsection{Cooperative Learning Model}

Cooperative learning model is one of models that can be used in a learning process through which students work together in small groups and are rewarded for the success of their group (Cruisckshank, Bainer, \& Metcalf, 2006). The cooperation aims to master learning materials previously presented by their teacher (Slavin, 1995). According to Henson and Eller (1999), students work together to achieve a common goal in cooperative learning. Cooperation in small groups can improve learning productivity, positive interpersonal relationships, and encourage each other to do their best (Sharan, 1980; Hoven, Berkum, \& Koopmans, 1987).

In cooperative learning, groups that succeed to achieve learning goals and objectives will be rewarded. Reward provision for these groups will encourage group members to help each other master the learning materials and achieve their common goal (Clarizio, 1987). This is in line with the opinion of Webb and Palincsar (1996), the awards the group is an attempt to empower a group function by increasing the individual's responsibility. Each student is responsible for learning and motivates them to help the group work, work hard, and help others.

In general, cooperative learning has two objectives: common and individual objectives. This objective has a philosophical meaning, one for all and all for one (Cruisckshank, Bainer, \& Metcalf, 2006). According to Arends (1998), there are at least three important learning objectives to be achieved through the development of cooperative learning model, namely: academic achievement, acceptance of diversity and the development of social skills. According to Leighton (1990), the success to improve academic achievement through cooperative learning model depends on three important characteristics, namely: group goals, individual accountability and same opportunities to succeed.

The purpose of the groups is usually expressed in the form of an award that is based on the group's success in the tasks in the academic field. To that end, the group must strive to earn rewards by mastering the material so well that it can improve the performance of each member of the group in the achievements they obtained previously (Leighton, 1990). This indicates that the group would be appreciated achievements, if all members of the group succeed in learning.

Individual responsibility is usually with regard to the assessment of each student's mastery of the material. Group members cooperate and train each other by testing each individual with multiple choice questions and short answers to demonstrate the skills independently. Their individual responsibilities, will allow all students the task in earnest. They concentrate their ability to share their ideas with each other, ask each other to each other and conduct an assessment to determine the level of understanding between each other, so no students who do 
not master the material (Leighton, 1990).

In addition to group goals and individual responsibility, equal opportunity to succeed can affect student achievement. Equal opportunity to succeed is visible from the group assessment system based on increasing individual score which exceeds the previous achievement scores. For student with low achievement, increased learning outcomes from $50 \%$ in the first quiz to $60 \%$ in the next quiz can donate to score groups, as well as with the increase learning outcomes for student with high achievement from $85 \%$ in the first quiz to $95 \%$ in the next quiz. Therefore it can be said that the two students are regarded as a valuable member of the group. The element of equal opportunity to succeed in the cooperative learning students reinforce the perception that academic achievement is obtained from the business students, not only from innate abilities. The same opportunity to succeed can arouse interest in achieving all group members and ensure that each member can help to win the group (Leighton, 1990). According to Johnson and Johnson (1989), there are five basic components of cooperative learning strategies; (1) the positive interdependence; (2) the face-to-face interaction; (3) individual responsibility; (4) cooperation skills; and (5) the group process (Johnson \& Johnson, 1989).

Positive achievement effects of cooperative learning model are present to almost all grade levels (2-12), in all major subjects, skills such as text processing, problem solving and writing and in urban, rural and suburban schools. Effects are equally positive for high, average and low achievers (O’Donnel, 1987; Reinhartz \& Beach, 1997; Elliot, 1999). In addition, cooperative learning can improve academic confidence and develop a sense of empathy and social cooperation (Ormrod, 2000). There are six major steps in cooperative learning model: (1) explaining the objectives and motivate students, (2) giving information, (3) organizing students in study groups, (4) guiding the groups to work and study, (5) evaluating and (6) giving reward (Arend, 1998; Ibrahim, 2006).

\subsubsection{Direct Instruction Model}

Direct instruction model is a learning model designed for students to learn structured knowledge which can be learned step by step (Arends, 1998). According to Burden and Byrd (2010), direct instruction model has four key components, namely: (1) the establishment of clear objectives; (2) teacher-directed learning; (3) carefully supervise student learning outcomes; (4) use of class organization and effective management methods. Direct instruction model is effective, because this model is based on the principles of learned behavior, such as gaining the attention of students, reinforce the correct response, provide corrective feedback, and practice the correct response.

The objective of direct instruction model is to enable students to master learning materials and develop skills (Arends, 1998; Burden and Byrd, 2010). Direct Instruction model requires specific behaviors and teacher's decisions during its planning and use to create a conducive learning environment. The use of direct instruction model stresses on students' mastery of declarative and procedural knowledge. In direct instruction model, mastery of concepts and students' behaviors is done deductively. Therefore, teachers should use different teaching methods and media so that learning will not be monotonous and boring (Suprihatiningrum, 2016). According to Arends (1998), there are five steps or syntaxes of direct instructional 
model: (1) explaining and setting learning goals, (2) explaining or demonstrating knowledge, (3) providing guided training, (4) checking understanding and giving feedback, and (5) providing advanced training.

\subsubsection{Achievement Motivation}

Motivation is processes that causes or lead to certain behaviors and provide direction, and resilience in the behavior (Santrock, 2008; Woolfolk; 2004, Irawan, Suciati, and Wardani, 1997). Motivation is a psychological phenomenon that is present in the individual and is a driving factor in meeting the needs of individuals to achieve goals (Suryobroto, 1993). At the core of motivation can be defined as: (1) the encouragement that arise in a person, is consciously or unconsciously, to perform an action with a particular purpose; (2) efforts that can cause a person or a particular group of people motivated to do something because they want to achieve certain goals (Asrori, 2009).

According to Indrawijaya, human motivation can be divided into three: achievement motivation, affiliation motivation and power motivation. Achievement motivation is a desire to do something as good as possible (Indrawijaya, 1989). Achievement motivation refers to their serious efforts to gain success or something in accordance with their objectives (Slavin, 1991; Stipek, 2002).

There are six indicators of people who have high achievement motivation, namely: (1) status as an expert, (2) persistent to achieve something, (3) perform through independence, (4) equal with peers, (5) is able to compete ; and (6) take advantage (Beck, 1990). Someone with a high achievement motivation is characterized by: 1) a strong desire to be responsible for solving his or her problems and doing his or her tasks; 2) a tendency to set more difficult achievement goals and calculate risks; 3 ) a strong desire to concentrate on his or her tasks, and 4) a personal thinking in accomplishing his or her own tasks (Steers, Porter, \& Bigley, 1991).

\section{Methodology}

\subsection{Place and Time of Research}

This study was conducted in two state Islamic elementary schools (Madrasah Ibtidaiyah Negeri - MIN) in Medan, namely Medan Tembung MIN and Medan Sunggal MIN. The research is conducted in the second semester of the 2015/2016 academic year.

\subsection{Methods and Research Design}

It was an experimental research. Its dependent variable was natural science learning outcomes, its independent variable was learning models and its attribute variable was achievement motivation. A $2 \times 2$ factorial experimental design was applied in the research in which each of the independent variables was classified into two phases. Below is a matrix of experimental design for this study. 
Table 1. Study Design Experiment 2 x 2

\begin{tabular}{|l|l|l|}
\hline & Treatment \\
\hline Variable (A) & Cooperative & Direct \\
& Learning & Instruction \\
Attribute Variable $(\mathrm{B})$ & $\begin{array}{l}\text { Model } \\
\left(\mathrm{A}_{1}\right)\end{array}$ & $\begin{array}{l}\text { Model } \\
\left(\mathrm{A}_{2}\right)\end{array}$ \\
\hline High Achievement Motivation $\left(\mathrm{B}_{1}\right)$ & $\mathrm{A}_{1} \mathrm{~B}_{1}$ & $\mathrm{~A}_{2} \mathrm{~B}_{1}$ \\
\hline Low Achievement Motivation $\left(\mathrm{B}_{2}\right)$ & $\mathrm{A}_{1} \mathrm{~B}_{2}$ & $\mathrm{~A}_{2} \mathrm{~B}_{2}$ \\
\hline
\end{tabular}

Information:

$\mathrm{A}_{1} \mathrm{~B}_{1} \quad$ : The group of students who have high achievement motivation

To learn natural science with cooperative learning model

$\mathrm{A}_{2} \mathrm{~B}_{1} \quad$ : The group of students who have high achievement motivation

To learn natural science with direct instruction model

$\mathrm{A}_{1} \mathrm{~B}_{2} \quad$ : groups of students have low achievement motivation

To learn natural science with cooperative learning model

$\mathrm{A}_{2} \mathrm{~B}_{2} \quad$ : groups of students have low achievement motivation

To learn natural science with direct instruction model

Furthermore, to address the threat of the validity of the experiment and the results can be generalized to the population, carried out the control of a number of variables with respect to internal and external validity of the experiment.

Threats to Internal Validity

Internal validity refers to the effort to control the experiment process so that the effects occur solely by the conditioned treatment (Wiersma, 1991). Control of internal validity in this case is intended to control the process of experimentation, so that learning outcomes in natural science is observed (research) is really a result of the treatment given learning.

Subject Characteristics. Selection of research subjects can lead to differences in individuals or groups that are not investigated due to the characteristics associated with the variables studied. This case is called the characteristics of the subjects (Fraenkel and Wallen, 1993). So that experimental results are not affected by differences in subject characteristics such as research subjects, conducted controlled manner; (1) choose a subject group of the population is characterized by relatively the same, (2) conduct randomized at the time of determining the class (school) which will be given treatment natural science learning with the learning model cooperative and class (school) which will be given treatment natural science learning with 
direct instructional model and (3) comparing the ability of early (evaluation of students learning outcomes value) between the two groups of subjects of the experiment before the treatment is given;

Loss of subject (mortality). Loss of subject (mortality) is a subject that is not constant follow the experiment. To avoid the influence of this mortality is recording of the subject has been identified as a potential unit of analysis from the beginning until the end of the process of the implementation of the experiment (Spector, 1993). The number of study subjects according to the results of measurements of achievement motivation and simple randomization is 30 students for natural science learning group with cooperative learning model and 30 students for natural science learning groups with direct instruction model;

Instrumentation. Instrumentation can be caused by instrument changes, including changes in scoring. Changes scoring controlled by providing scoring guidelines are thorough and complete. Besides the influence of instrumentation can also occur due to differences in the characteristics of the data collector. Different characteristics are controlled by using the same data collection tool for either the experimental group or for the control group (Fraenkel \& Wallen, 1993);

Testing. To avoid the influence of tests on the experimental results, the study was not conducted pre-test before treatment done (Fraenkel \& Wallen, 1993: 226);

History, the events are not associated with the treatment, which will occur during the experiment and affect the dependent variable (Neuman, 2003: 253). So that experimental results are not affected by the elements of this history, it is necessary that the learning process in the two groups of students studied during the research process, takes place in circumstances that are relatively similar, control (suspend) the activities of school programs that are expected to affect the achievement of the experimental results (learning outcomes in natural science);

Maturation. Maturation is some of the processes of biological, psychological, and emotional in the subject, which is more common in long-running experiments (Creswell, 2008). So that experimental results are not affected by factors of maturity, then during the research process underway to control against a number of intervention programs that are expected to stimulate maturation or refers to increased student achievement, such as the provision of extra lessons or tutoring (especially for natural science subjects) and the provision of special exercises outside the learning programs that have been designed or specified. In addition, the time span of treatment provision is determined to be too long, only one unit of time studying at state Islamic elementary school (MIN), ie one semester;

Attitude of subjects. How to view the subject of the research and involvement in the experiment can affect the internal validity. Controlling the attitude of the subject do not notify that the student is the subject of research (Fraenkel \& Wallen, 1993);

Regression. Statistical regression influence arises because of the extreme scores in the study. The influence of statistical regression in this study are controlled by equating or comparison group (Fraenkel \& Wallen, 1993), by selecting the two schools that have relatively the same characteristics of the subjects, which have relatively the same early-ability students. 
Statistically the two groups studied had same prior knowledge of natural science there are not students who have extreme low or high ability;

Implementation. The implementation is unexpected events that can benefit any one group. To avoid the effect of implementation of this research is done by selecting the teachers equivalent to the experimental group and the control group, both in terms of education and experience (both educated S1 with work experience as a teacher at state Islamic elementary school (MIN) 12 and 11 years) and make treatment instrument itself (Fraenkel \& Wallen, 1993), as a reference to carry out the study treatment (experiment) in the form of learning program. The design of the learning program made reference to the type of treatment, experimenters stay implement steps or stages have been developed.

\section{Threats to External Validity}

External validity control meant that experimental results can be generalized to the population and environmental conditions outside the experimental context (Macmillan \& Schumacher, 2001). For this, need to control, the validity of the population and ecological validity. Control of the validity of the population, is done by selecting a sample (research subjects) in accordance with the characteristics of the population through methodological procedures that can be accounted for and perform randomization when determining the subject to be subjected to the study treatment, while the control of ecological validity, conducted in the following manner.

Do not change condition and atmosphere class, let the learning conditions as usually (Borg and Gall, 1996). For this, the treatment of learning is given in accordance with the timetable in schools, the classroom teachers who served in the relevant class as an experimenter, let the research subject is in a class and learn with other students in the class (school) as usual, and give the same treatment on all students in the class;

Monitor the implementation of the experiment is not overtly, but more subtly through observation, discussion with students and teachers outside of school hours. Third, provide instructional treatment that has been set (Borg and Gall, 1996). It is, to avoid the effect of treatment is not expected.

\subsection{Population and Sampling Techniques Research}

The research population was all students at the fifth grade of State Islamic Elementary School (MIN) in Medan, Indonesia. The research samples were taken through the following stages.

Identifying and choosing two state Islamic elementary schools in Medan, Indonesia, as the research locations by applying a purposive sampling technique. Then, the writer identified and chose Medan Tembung State Islamic Elementary School and Medan Sunggal State Islamic Elementary School as the research locations. The two schools have some similar characteristics such as school ranking in Medan, school social environmental graphic and quality of natural science teachers.

Choosing the two schools randomly to be an experimental group and a control group. Medan Tembung State Islamic Elementary School composed of 54 students was chosen to be the 
experimental group and Medan Sunggal State Islamic Elementary School consisting of 55 students was chosen as the control group.

Each group is divided into two groups of students who have high achievement motivation and groups of students who have low achievement motivation. Determination of student achievement motivation conducted by use Likert scale model. Scores obtained from measurements using Likert scale model later in the ranking. As many as $27 \%$ of the high group is expressed as a group that has a high achievement motivation, while $27 \%$ lower group expressed as groups that have low achievement motivation. Making each $27 \%$ high group and low group of all participants to sort of achievement motivation was based on the recommendation of Popham (1981). In line with Popham, in sorting out the high group and the low group, Osterlind suggest that upper group and lower group is determined by selecting $27 \%$ of all participants (Osterlind, 1989). Thus, the students were categorized as having high achievement motivation were 15 students from Medan Tembung State Islamic Elementary School and 15 students from Medan Sunggal State Islamic Elementary School. Likewise were categorized as having low achievement motivation are 15 students from Medan Tembung State Islamic Elementary School and 15 students from Medan Sunggal State Islamic Elementary School. Thus, the sample for this study consisted of: (1) a group of students who have high achievement motivation will be taught by cooperative learning model as many as 15 people, (2) a group of students who have high achievement motivation will be taught with direct instruction model as much as 15 person, (3) a group of students who have low achievement motivation will be taught by cooperative learning model as many as 15 people, (4) a group of students who have low achievement motivation will be taught by direct instruction model as many as 15 people.

Table 2 below shows compositions of the research samples taken by using the above sampling technique.

Table 2. Research samples by location and type of treatment

\begin{tabular}{|c|c|c|c|}
\hline & Location and Typ & ff Treatment & \\
\hline \multirow[t]{2}{*}{$\begin{array}{l}\text { Achievement } \\
\text { Motivation }\end{array}$} & $\begin{array}{l}\text { Medan Tembung } \\
\text { State Islamic } \\
\text { Elementary } \\
\text { School }\end{array}$ & $\begin{array}{l}\text { Medan Sunggal } \\
\text { State Islamic } \\
\text { Elementary } \\
\text { School }\end{array}$ & \multirow[t]{2}{*}{ Total } \\
\hline & $\begin{array}{l}\text { Cooperative } \\
\text { Learning Model }\end{array}$ & $\begin{array}{l}\text { Direct Instruction } \\
\text { Model }\end{array}$ & \\
\hline High & 15 & 15 & 30 \\
\hline Low & 15 & 15 & 30 \\
\hline Total & 30 & 30 & 60 \\
\hline
\end{tabular}




\subsection{Treatment Research}

Treatment research in this regard is the implementation of an experiment in the form of learning natural science by using the cooperative model on the one hand and with the direct model on the other side. The treatment is given for one unit of study in MIN, ie one semester.

\subsection{Research Instruments}

Data collection instruments used in the research included learning outcome test and achievement motivation scale. The learning outcome test was used to measure natural science learning result variable while the achievement motivation scale was used to measure achievement motivation variable.

\subsection{Data Analysis Technique}

A data analysis technique was needed in the research to describe research data in general and test the research hypothesis. A descriptive statistic was used to describe the data and a two-way analysis of variance (ANOVA) was used to test the research hypothesis. Before the data analysis is done first test statistical analysis requirements that test for normality and homogeneity. The hypothesis that is tested in this study as follows:

a. Hypothesis $1: \mathrm{H}_{0}: \quad \mu_{\mathrm{A} 1}=\mu_{\mathrm{A} 2}$

$$
\mathrm{H}_{1}: \mu_{\mathrm{A} 1}>\mu_{\mathrm{A} 2}
$$

b. Hypothesis $2: \mathrm{H}_{0}: \quad \mu_{\mathrm{A} 1 \mathrm{~B} 1}=\mu_{\mathrm{A} 2 \mathrm{~B} 1}$

$$
\mathrm{H}_{1}: \mu_{\mathrm{A} 1 \mathrm{~B} 1}>\mu_{\mathrm{A} 2 \mathrm{~B} 1}
$$

c. Hypothesis $3: \mathrm{H}_{0}: \quad \mu_{\mathrm{A} 1 \mathrm{~B} 2}=\mu_{\mathrm{A} 2 \mathrm{~B} 2}$

$$
\mathrm{H}_{1}: \mu_{\mathrm{A} 1 \mathrm{~B} 2}<\mu_{\mathrm{A} 2 \mathrm{~B} 2}
$$

d. Hypothesis $4: \mathrm{H}_{0} \quad$ : Int. A x B =0

$$
\mathrm{H}_{1} \quad \text { : Int. } \mathrm{A} \times \mathrm{B} \neq 0
$$

Information:

$\mathrm{H}_{0}$ : The null hypothesis

$\mathrm{H}_{1}$ : The alternative hypothesis

$\mu_{\mathrm{A} 1}$ : mean of students learning outcomes in natural science taught by

Cooperative learning model

$\mu_{\mathrm{A} 2}:$ mean of students learning outcomes in natural science taught by

Direct instruction model

$\mu_{\mathrm{B} 1}$ : mean of students learning outcomes in natural science who have high

Achievement Motivation 
$\mu_{\mathrm{B} 2} \quad$ : mean of students learning outcomes in natural science who have low

Achievement Motivation

$\mu_{\mathrm{A} 1 \mathrm{~B} 1} \quad$ : mean of students learning outcomes in natural science who have high

Achievement motivation taught by cooperative learning model

$\mu_{\mathrm{A} 2 \mathrm{~B} 1} \quad$ : mean of students learning outcomes in natural science who have

High achievement motivation taught by direct instruction model

$\mu_{\mathrm{A} 1 \mathrm{~B} 2}$ : mean students learning outcomes in natural science who have low achievement

Motivation taught by cooperative learning model

$\mu_{\mathrm{A} 2 \mathrm{~B} 2}$ : mean of students learning outcomes in natural natural science who have low

Achievement motivation taught by direct instruction model

4. Result and Discussion

4.1 Result

Overall the data of natural science learning outcomes is presented in Table 3 below.

Table 3: Data on Students' Natural Science Learning Outcomes

\begin{tabular}{|l|l|l|l|}
\hline & \multicolumn{2}{|l|}{ Learning Model } & \\
\hline Achievement & $\begin{array}{l}\text { Cooperative } \\
\text { Learning } \\
\text { Modivation }\end{array}$ & $\begin{array}{l}\text { Direct } \\
\text { Instruction } \\
\text { Model }\end{array}$ & Total \\
\hline \multirow{3}{*}{ High } & $\mathrm{n}=15$ & $\mathrm{n}=15$ & $\mathrm{n}=30$ \\
& $\bar{X}=42.15$ & $\bar{X}=29.88$ & $\bar{X}=36.02$ \\
& $\mathrm{~s}=3.77$ & $\mathrm{~s}=7.67$ & $\mathrm{~s}=5.72$ \\
\hline \multirow{5}{*}{ Low } & $\mathrm{n}=15$ & $\mathrm{n}=15$ & $\mathrm{n}=30$ \\
& $\bar{X}=32.68$ & $\bar{X}=40.20$ & $\bar{X}=36.44$ \\
& $\mathrm{~s}=7.20$ & $\mathrm{~s}=4.32$ & $\mathrm{~s}=5.76$ \\
\hline \multirow{5}{*}{ Total } & $\mathrm{n}=30$ & $\mathrm{n}=30$ & \\
& $\bar{X}=37.42$ & $\bar{X}=33.29$ & \\
& $\mathrm{~s}=5.49$ & $\mathrm{~s}=5.99$ & \\
\hline
\end{tabular}

Table 4 below shows results of data analysis of natural science learning outcomes by using a two-way analysis of variance (ANOVA). 
Table 4. Results of data analysis of natural science learning outcomes by using a two-way analysis of variance (ANOVA)

\begin{tabular}{|c|c|c|c|c|c|c|}
\hline \multirow{2}{*}{$\begin{array}{l}\text { Sources of } \\
\text { Variation }\end{array}$} & \multirow{2}{*}{$\begin{array}{l}\text { Sums of } \\
\text { Squares }\end{array}$} & \multirow{2}{*}{$\begin{array}{l}\text { Degrees of } \\
\text { Freedom }\end{array}$} & \multirow{2}{*}{$\begin{array}{l}\text { Mean } \\
\text { Square }\end{array}$} & \multirow[t]{2}{*}{$\mathrm{F}_{0}$} & \multicolumn{2}{|l|}{$F_{t}$} \\
\hline & & & & & $\begin{array}{l}\alpha= \\
0.05\end{array}$ & $\begin{array}{l}\alpha= \\
0.01\end{array}$ \\
\hline $\begin{array}{l}\text { Instructional Model } \\
\text { (A) }\end{array}$ & 396.01 & 1 & 396.01 & $7.82 *$ & 4.00 & 7.08 \\
\hline $\begin{array}{l}\text { Achievement } \\
\text { Motivation } \\
\text { (B) }\end{array}$ & 33.28 & 1 & 33.28 & $0.66^{\mathrm{ns}}$ & 4.00 & 7.08 \\
\hline $\begin{array}{l}\text { Interaction } \\
(\mathrm{AB})\end{array}$ & 957.66 & 1 & 957.66 & $18.92 * *$ & 4.00 & 7.08 \\
\hline $\begin{array}{l}\text { Within Group } \\
\text { (D) }\end{array}$ & 2785.31 & 56 & 50.61 & - & - & - \\
\hline Total Reduction & 4182.52 & 59 & - & - & - & - \\
\hline
\end{tabular}

* Significant at $\alpha=0.05$

** Significant at $\alpha=0.01$

ns $=$ non significant

Based on the results of data analysis of natural science learning outcomes by using a two-way analysis of variance (ANOVA) presented in above Table 2, the followings points were found.

1). Differences in Students' Natural Science Learning Outcomes by Learning Models

Results of data analysis by using two-way analysis of variance (ANOVA) show that the value of $F_{\text {calculate }}$ (7.82) was higher than the value of $F_{\text {table }}$ (4.00) for the significance level of 0.05 . This means that $\mathrm{H}_{0}$ is rejected and $\mathrm{H}_{1}$ is accepted. The analysis shows that there is a significant difference in effects of cooperative learning model and direct instruction model on natural science learning outcomes.

The research found that the average score of natural science of students who were taught by using a cooperative learning model was 37.42 and the average score of natural science of students who were taught by using a direct instructional model was 33.29. So, the two-way analysis of variance (ANOVA) test shows that students who were taught by using a cooperative learning model had higher natural science learning outcomes than those who were taught by using a direct instruction model.

2). Differences in Natural Science Learning Outcomes of Students with High Achievement Motivation by Learning Models

The research found that the average score of natural science of students with high achievement motivation who were taught by using a cooperative learning model was 42.15 and the average score of natural science of students with high achievement motivation who were taught by 
using a direct instructional model was 29.88. The mean square within groups calculated by using the two-way analysis of variance (ANOVA) was 50.61.

Then, a Tukey test was done to identify which groups of students that had a higher natural science learning outcomes. Results of the test show that the $\mathrm{Q}_{\text {calculate }}$ was 12.27 and the $\mathrm{Q}_{\text {table }}$ was 2.83 for the significance level of 0.05 and 3.82 for the significance level of 0.01 . Since the

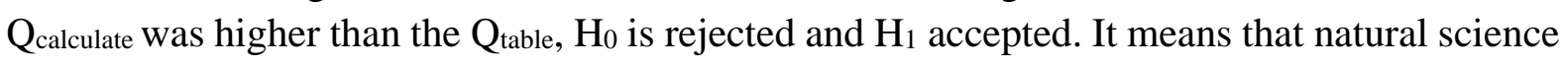
learning outcomes of students with high achievement motivation who were taught by using a cooperative learning model was higher than those of students with high achievement motivation who were taught by using a direct instruction model. Table 5 below shows results of the Tukey test.

Table 5. Differences in Natural Science Learning Outcomes of Students with High Achievement Motivation by Learning Models

\begin{tabular}{|c|c|c|c|c|c|}
\hline \multirow[t]{2}{*}{ Learning Model } & \multirow{2}{*}{$\begin{array}{l}\text { Cooperative } \\
\text { Learning }\end{array}$} & \multirow{2}{*}{$\begin{array}{l}\text { Direct } \\
\text { Instruction }\end{array}$} & \multirow[t]{2}{*}{$\mathrm{Q}_{\text {calculate }}$} & \multicolumn{2}{|l|}{$Q_{\text {table }}$} \\
\hline & & & & $\begin{array}{l}\alpha \\
0.05\end{array}=$ & $\begin{array}{l}\alpha \\
0.01\end{array}$ \\
\hline Mean & 42.15 & 29.88 & \multirow{3}{*}{12.27} & \multirow{3}{*}{2.83} & \multirow{3}{*}{3.82} \\
\hline $\begin{array}{l}\text { Mean Squares } \\
\text { Within Groups }\end{array}$ & 50.61 & & & & \\
\hline $\begin{array}{l}\text { Degrees } \\
\text { Freedom }\end{array}$ & 56 & & & & \\
\hline
\end{tabular}

Differences in Natural Science Learning Outcomes of Students with Low Achievement Motivation by Learning Models

The research found that the average score of natural science of students with low achievement motivation who were taught by using a cooperative learning model was 32.68 and the average score of natural science of students with low achievement motivation who were taught by using a direct instructional model was 40.20. So, mean square within group calculated by using the two-way analysis of variance (ANOVA) was 50.61 .

Then, a Tukey test was also done to identify which groups of students that had a higher natural science learning outcomes. Results of the test show that the $\mathrm{Q}_{\text {calculate }}$ was 5.78 and the $\mathrm{Q}_{\text {table }}$ was 2.83 for the significance level of 0.05 and 3.82 for the significance level of 0.01 . Since the $\mathrm{Q}_{\text {calculate }}$ was higher than the $\mathrm{Q}_{\text {table }}, \mathrm{H}_{0}$ is rejected and $\mathrm{H}_{1}$ accepted. It means that natural science learning outcomes of students with low achievement motivation who were taught by using a direct instruction model was higher than those of students with high achievement motivation who were taught by using a cooperative learning model. Table 6 below shows results of the Tukey test. 
Table 6. Differences in Natural Science Learning Outcomes of Students with Low Achievement Motivation by Learning Models

\begin{tabular}{|l|l|l|l|l|l|}
\hline Learning & Coopeative & Direct \\
Model & Learning & Instruction & \multirow{2}{*}{\begin{tabular}{l} 
Qalculate \\
\cline { 5 - 6 }
\end{tabular}} & $\begin{array}{l}Q_{\text {table }} \\
0.05\end{array}$ & $\begin{array}{l}\alpha= \\
0.01\end{array}$ \\
\hline Mean & 32.68 & 40.20 & 5.78 & 2.83 & 3.82 \\
\hline $\begin{array}{l}\text { Mean Squares } \\
\text { within Group }\end{array}$ & 50.61 & & & \\
\hline $\begin{array}{l}\text { Degrees of } \\
\text { Freedom }\end{array}$ & 56 & & & \\
\hline
\end{tabular}

Interaction between Learning Model and Achievement Motivation and its Effects on Natural Science Learning Outcomes

Results of the second and the third hypothesis indicate that there was an interaction between learning model and achievement motivation and its effects on natural science learning outcomes. Results of data analysis by using two-way ANOVA supported the indication because based on the results of data analysis by using two-way ANOVA, the value of $\mathrm{F}_{\text {calculate }}$ (18.92) was higher than the value of $F_{\text {table }}(4.00)$ for the significance level of 0.05 and $F_{\text {table }}$ was 7.08 for the significance level of 0.01 . Therefore, $\mathrm{H}_{0}$ is rejected and $\mathrm{H}_{1}$ accepted. So, there is an interaction between learning model and achievement motivation and its effects on natural science learning outcomes.

\subsection{Discussion}

Based on the results of the research hypothesis testing, there are some points that need to be further debated or discussed. The first is differences in natural science learning outcomes of students who are taught by using a cooperative learning model and those of taught by using a direct instruction model. The research found that natural science learning outcomes of students who were taught by using a cooperative learning model were higher than those of students who were taught by using a direct instruction model. This is in line with what Slavins (1995) says. He says that positive achievement effects of cooperative learning model are present to almost all grade levels (2-12), in all major subjects, skills such as text processing, problem solving and writing and in urban, rural and suburban schools. Effects are equally positive for high, average and low achievers. Similarly, Arends (1998) states that the development of cooperative learning model not only aims to improve academic achievement and acceptance of diversity but also aims to develop social skills. Through cooperative learning model, students with different backgrounds and conditions have an opportunity to cooperate to achieve their common goal through reward provision and mutual respect.

The second is differences in natural science learning outcomes of students with high achievement motivation who are taught by using a cooperative learning model and those of students with high achievement motivation who are taught by using a direct instruction model. The research found that natural science learning outcomes of students with high achievement 
motivation who were taught by using a cooperative learning model was higher than those of students with high achievement motivation who were taught by using a direct instruction model. This is because students with high achievement motivation have individual goal and accountability. Both individual goal and accountability are needed for effective and efficient use of cooperative learning model. These two factors encourage students to help each other in learning. If the two factors are absent, they will not be encouraged to help each other achieve their learning goals. This is in line with what Leighton (1990) says. He says that the success to improve academic achievement through cooperative learning model depends on three important characteristics, namely: group goals, individual accountability and same opportunities to succeed. This is also in line with the results of research Mursidah (2002) which shows that students who have high achievement motivation will be better result of learning if taught by cooperative learning model.

The third is differences in natural science learning outcomes of students with low achievement motivation who are taught by using a cooperative learning model and those of students with low achievement motivation who are taught by using a direct instruction model. The research found that natural science learning outcomes of students with low achievement motivation who were taught by using a cooperative learning model were lower than those of students with low achievement motivation who were taught by using a direct instruction model. This is because students with low achievement motivation tend to be less accountable, less confident, less active and more dependent on others in accomplishing their tasks. Therefore, teacher's greater role is needed in explaining lessons during teaching and learning process. Teachers play more active role in direct instruction model than in cooperative learning model to help students, especially those who are lack of self-confidence, improve their understanding of the lessons. This is in line with what Suprihatiningrum (2016) says. She says that direct instruction model is useful for students who do not have self-confidence or skills to do their tasks. This is also in line with Burden and Byrd's (2010) view, that students learn basic skills more quickly when they receive direct instruction in a larger portion of their teachers. Thus, it is understandable that natural science learning results of students with low achievement motivation who were taught by using a cooperative learning model were lower than those of students with low achievement motivation who were taught by using a direct instruction model.

The fourth is interaction between learning model and achievement motivation and its effects on natural science learning outcomes. The research found that there was an interaction between learning model and achievement motivation and its effects on natural science learning outcomes. This shows that the effectiveness of a learning model is related to the characteristics of students being taught. Therefore, a cooperative learning model needs to be used for students with high achievement motivation and a direct instruction model needs to be used for students with low achievement motivation to improve their natural science learning outcomes.

However much research has been made to the fullest, objectively there are still limitations that must be acknowledged and should be put forward as consideration to interpret and generalize the results achieved. First, however, because the research is done in the learning process in the classroom (school), the implementation of the experiment needs to adjust to the learning schedule in the school and the various binding rules in the school, the influence of student 
interaction with various learning processes outside the research context is not fully controlled.

Second, research is conducted at different schools and teacher sites. This is in one hand taken in an effort to overcome the threat of internal validity of the experimental process, namely to avoid the occurrence of contamination of research subjects so that between students who gain learning with cooperative models and who obtain learning with direct model does not influence each other and to avoid the factor of personal subjectivity in giving treatment differently in different groups of students. But the threat of external validity of experiments especially with regard to ecological conditions and the influence of teacher subjectivity is not entirely insurmountable.

Third, the study was conducted in a very limited school unit with a relatively small sample size of 60 students divided into four groups. Under these conditions, the generalization of the results of the study applies only to schools that have similar characteristics to the schools in which the research is conducted. Similarly to the very small sample size, the statistical decision power generated to support the conclusions of the research results is weakened or reduced.

Fourth, the research instrument used in this study is not a standard instrument. However the data collection tool used has been developed by following the required methodological procedures from the study of theory, the translation of constructs into dimensions and indicators, developing it in the form of instrument items, testing, validity of grains for selection, and calculating reliability, then constructing it in a set of data collection tools, as the instrument of self-development (by researchers) is still not free from limitations and shortcomings.

With regard to these limitations, to practitioners and users of findings that will apply and / or further develop is expected to pay attention to the weak points of this research, as well as to similar field developers, it is desirable to exploit these limitations as inputs for Doing further research.

\section{Conclusions}

Based on the above research findings, it can be concluded that a cooperative learning model can improve students' natural science learning outcomes. However, students' achievement motivation must also be carefully considered to optimize their natural science learning outcomes. Natural science learning outcomes of students with high achievement motivation who were taught by using a cooperative learning model were higher than those of students with high achievement motivation who were taught by using a direct instruction model. Meanwhile, natural science learning outcomes of students with low achievement motivation who were taught by using a cooperative learning model were lower than those of students with high achievement motivation who were taught by using a direct instruction model. Based on the above conclusion, it is important to improve students' achievement motivation to ensure that cooperative learning model can be used effectively.

\section{Acknowledgements}

The writer's sincere thanks shall go to the principals of Medan Tembung State Islamic Elementary School and Medan Sunggal State Islamic Elementary School who have 
participated in the study as a provider of research site.

\section{References}

Al-Rasyidin, A. R., \& Nasution, W. N. (2015). Teori belajar dan pembelajaran. Medan: Perdana Publishing.

Anderson, O. W., \& Krathwohl, D. R. (Ed.). (2001). A taxanomy for learning, teaching, and assessing: a revision of Bloom taxonomy of educational objectives. New York: Addison Wesley Longman, Inc.

Arends, R. I. (1998). Learning to teach (4 ${ }^{\text {th }}$ ed.). Boston: McGraw-Hill.

Asrori, M. (2009). Psikologi pembelajaran. Bandung: CV Wacana Prima.

Beck, R. C. (1990). Motivation theories and principles. Englewood Cliffs, New Jersey: Prentice Hall.

Benchmark, F., Jack, R., \& Norman, E. W. (1993). How to design and evaluate research in education ( $2^{\text {nd }}$ ed.). New York: McGraw-Hill Inc.

Bloom, B. S. (1975). Taxanomy of educational objectives. London: Longman.

Borg, W. R., \& Gall, M. D. (1996). Educational research: an introduction. Boston: Allyn and Bacon.

Burden, P. R., \& Byrd, D. M. (2010). Methods for effective teaching: meeting the needs of all students ( $5^{\text {th }}$ ed.). Boston: Allyn \& Bacon.

Cain, S. E., \& Evans, J. M. (1990). Sciencing: an involvement approach to elementary natural science methods. Columbus: Merill Publishing Company.

Carin, A. A., \& Sund, R. B. (1989). Teaching natural science through discovery. Colombus, Ohio: Merill Publishing Company.

Clarizio, H. F., Craig, R. C., \& Mehrens,W. A. (1987). Contemporary educational psychology (New York: McGraw-Hill Book Company).

Creswell, J. W. (2008). Educational research: planning, conducting and evaluating qualilative and quantitative research ( $3^{\text {rd }}$ ed.). New Jersey: Pearson Prentice Hall.

Cruisckshank, D. R., Jenkins, D. B., \& Metcalf, K. K. (2006). The act of teaching (4 ${ }^{\text {th }}$ ed.). New York: McGraw-Hill, Inc.

Elliot, S. N. (1999). Educational psychology: effective teaching, effective learning .Chicago: Brown \&

Gagne R. J., \& Briggs, L. J. (1979). Principles of instructional design (2nd ed.). New York: Holt Rinehart and Winston.

Henson, K. T., \& Eller, B. F. (1999). Educational psychology for effective teaching (Boston: Wadsworth Publishing Company. 


\section{Macrothink}

Hoven, J. P. V. O., Berkum, G. V., \& Koopmans, T. S. (1987). Effect of cooperation and shared feedback on spelling achievement. Journal of Educational Psychology, 79(1), 92.

Ibrahim, M. (2006). Pembelajaran kooperatif. Surabaya: PSMS UNESA.

Indrawijaya, A. I. (1989). Perilaku organisasi. Bandung: Sinar Baru.

Irawan, P., \& Suciati, W. (1997). Teori Belajar, Motivasi, dan Keterampilan Mengajar. Jakarta: Depdikbud.

Johnson, D. W., \& Johnson, R. T. (1989). Cooperative learning. In L. W. Anderson (Ed.). The effective teacher: study, guide, and readings (pp. 178-181). New York: McGraw-Hill Book Company.

Krajcik, J. S., Czerniak, C. M., \& Berger, C. (1999). Teaching children natural science: a project-based approach. Boston: McGraw-Hill.

Leighton, M. S. (1990). Cooperative learning. In J. M. Cooper (Ed.), Classroom teaching skills (pp. 309-322.). USA: D. C. Heath and Company.

Maccmillan, J. H., \& Schumacher, S. (2001). Research in education: a conceptual introduction. New York: Long Man.

McClelland, D. C., Atkinson, J. W., Clark, R. A., \& Lowell, E. L. (1976). The achievement motive. New York: Irvington Publishers, Inc.

Mursidah, S. (2002). Pengaruh strategi pembelajaran dan motivasi berprestasi terhadap hasil belajar matematika: Studi eksperimen pada siswa kelas 2 SLTPN 1 Banjar Negara. Thesis. Jakarta: Universitas Negeri Jakarta.

Neuman, W. L. (2003). Social research methods: qualitatif and quantitatif approaches. Boston: USA, 2003.

O’Donnel, A. M. (1987). Social/affective and metacognitive outcomes of scripted cooperative learning. Journal of Educational Psychology, 79(4), 431.

Ormrod, J. E. (2000). Educational psychology: developing learners ( $3^{\text {rd }}$ ed.). London: Merill.

Osterlind, S. J. (1989). Constructing test items. Boston: Kluwer Academic Publishers.

Popham, J. W. (1981). Modern educational measurement. New Jersey: Prentice Hall, Inc.

Priyono, \& Sayekti, T. (2010). IPA untuk SD dan MI Kelas V. Jakarta: Pusat Perbukuan, Kemendiknas.

Reinhartz, J. (1997). Teaching and learning in the elementary school: Focus on curriculum. Prentice Hall.

Romiszowski, A. J. (1981). Designing instruction system. London: Kogan Page Ltd.

Santrock, J. W. (2008). Educational psychology (3 ${ }^{\text {rd }}$ ed.). Boston: McGraw Hill.

Sharan, S. (1980). Cooperative learning in small group. recent methods and effect of 
achievement, attitude and ethnic relations. Review of Educational Research, 50(2), 267.

Slavin, R. E. (1995). Cooperative learning: theory, research, and practice ( $\left.2^{\text {nd }} \mathrm{ed}.\right)$. London : Allyn and Bacon.

Soedijarto. (1993). Menuju pendidikan nasional yang relevan dan bermutu. Jakarta: Balai Pustaka.

Spector, P. E. (1993). Research design. In M. S. L. Beck (Ed.), Experimental design and methods. Singapore: Sage Publications Toppan Publishing.

Steers, R. M., Poter, L. W., \& Bigley, G. A. (1991). Motivation and leadership at work. New York: McGraw-hill Companies, Inc.

Stipek, D. (2002). Motivation to learn: integrating theory and practice $\left(4^{\text {th }} \mathrm{ed}\right.$.). Boston: Allyn \& Bacon.

Sumaji, D. (1998). Pendidikan sains yang humanistis .Yogyakarta: Kanisius.

Suprihatiningrum, J. (2016). Strategi pembelajaran: teori dan aplikasi. Jogyakarta: Ar-Ruzz Media.

Suryabrata, S. (2005). Psikologi pendidikan. Jakarta: Rajawali Pers.

Suryobroto, S. (1993). Psikologi kepelatihan. Jakarta: CV. Jaya Sakti.

Webb, N. M., \& Palincsar, A. S. (1996). Group processes in the classroom. In C. B. David \& C. C. Robert (Ed.), Handbook of Educational Psychology. New York: Maccmilan Library Reference USA. p. 857.

Wiersma, W. (1991). Research methods in education. Boston: Allyn and Bacon.

Woolfolk, A. (2004). Educational psychology (9th ed.). Boston: Pearson.

\section{Copyright Disclaimer}

Copyright reserved by the author(s).

This article is an open-access article distributed under the terms and conditions of the Creative Commons Attribution license (http://creativecommons.org/licenses/by/3.0/). 